\title{
The Change in Chaucerian Aesthetics: From The Tale of Sir Thopas to The Tale of Melibee
}

\author{
Chaucer Estetiğindeki Değişim: \\ Sir Thopas 'in Hikayesi'nden Melibee'nin Hikayesi'ne
}

\section{Oya BAYILTMIŞ ÖĞ̈̈TCÜ *}

\begin{abstract}
Chaucer's The Tale of Sir Thopas and The Tale of Melibee exhibit the transformation from the romance tradition to philosophical narration, exaggerating romance as an unrealistic narration and presenting philosophical narration as a more realistic literary form. Chaucer the pilgrim firstly starts with romance (The Tale of Sir Thopas) and then continues with a philosophical tale (The Tale of Melibee), which is derived from Boethius's Consolation of Philosophy. In this respect, the role of Chaucer the pilgrim is very important to display the change in Chaucerian literary aesthetics. Furthermore, displaying the negative attitudes of the pilgrims, as a representative audience, towards The Tale of Sir Thopas, which starts with the interruption of the tale, and the positive remarks of the pilgrims towards The Tale of Melibee, Chaucer exhibits the reception process of his tales, which can be defined as the reflection of the literary aesthetics not only of the poet but also on the part of the audience/readers. Hence, it can be suggested that, presenting the approval of a more realistic philosophical narrative, Chaucer not only reflects the change in literary aesthetics, but also shapes this change in literary aesthetics. Thus, the aim of this article is to discuss the literary aesthetics of the change from romance to philosophical narration, and to claim that this representation of literary aesthetics is functional in displaying Chaucer's literary selffashioning.
\end{abstract}

Keywords: Chaucer, The Tale of Sir Thopas, The Tale of Melibee, romance, philosophical narration, literary aesthetics, literary self-fashioning

Öz: Chaucer'ın Sör Thopas'ın Hikayesi ve Melibee'nin Hikayesi, romansı gerçekdışı bir edebi anlatım biçimi olarak abartarak ve felsefi anlatımı daha gerçekçi bir edebi tür olarak sunarak, romans geleneğinden felsefi anlatıma geçişi sergiler. Hacı Chaucer ilk önce romans (Sör Thopas 'ın Hikayesi) ile başlar ve sonrasında, Boethius'un Felsefenin Tesellisi eserinden esinlenen felsefi bir hikaye (Melibee'nin Hikayesi) ile devam eder. Bu açıdan, hacı Chaucer'ın rolü Chaucer'ın edebi estetiğindeki değişimi yansıtmak için çok önemlidir. Dahası, temsili seyirciler olarak hacıların Sör Thopas'ın Hikayesi'nin yarıda kesilmesini takiben olumsuz tepkilerini, Melibee'nin Hikayesi sonrası ise olumlu tepkilerini sunarak, Chaucer sadece şairin değil aynı zamanda dinleyicilerinin/okuyucularının edebi estetik anlayışlarının da bir yansıması olan, hikayelerin algılanış sürecini de sergilemektedir. Bu yüzden, daha gerçekçi olan bir felsefi anlatımın beğenisini sunarak, Chaucer'ın sadece edebi estetikteki değişimi yansıttığı değil, aynı zamanda bu değişimi şekillendirdiği de söylenebilir. Bu sebeple, bu makalenin amacı edebi estetikteki romanstan felsefi anlatıma geçişi tartışmak ve edebi estetiğin bu temsilinin Chaucer'ın edebi öz-biçimlendirmesini göstermekte önemli olduğunu iddia etmektir.

Anahtar sözcükler: Chaucer, Sör Thopas'ın Hikayesi, Melibee'nin Hikayesi, romans, felsefi anlatım, edebi estetik, edebi öz-biçimlendirme

Dr, Adiyaman University, Faculty of Science and Letters, Department of English Language and Literature, Adıyaman.oyabayiltmis@gmail.com

This article is the expanded and revised version of the paper presented at The International Two-Day Conference at the National University of Ireland, Galway, Chaucer at Galway 2: Chaucer and Realism (25-26 June 2014) organised by the National University of Ireland, Galway. 
Stephen Greenblatt defines self-fashioning in his book entitled Renaissance Self-Fashioning: From More to Shakespeare as "the Renaissance version of [...] [the] control mechanisms, the cultural system of meanings that creates specific individuals by governing the passage from abstract potential to concrete historical embodiment" (2005, 3-4). Self-fashioning refers to the control of external forces as well as internal ones that have influence over an individual's identity formation. In this identity formation process, Greenblatt emphasises the role of writers and their literary works "to fashion other selves" (2005, 3), since writers present examples for people to fashion their identities. Furthering Greenblatt's arguments in relation to the selffashioning concept, this article suggests that literary works set examples not only to fashion individual selves, but also to fashion literature itself through literary arguments or through the comparison and contrast of certain genres constituting a kind of discussion between different genres or different narrative patterns. These forms of literary practice can be defined as the products of a writer's literary self-fashioning. A writer creates a space in her/his works for the discussion of changing literary aesthetics. In this literary space, she/he both reflects the change in her/his own literary aesthetics and in the literary aesthetics of her/his time. Hence, these literary practices of a writer should also be regarded as the means through which the writer shapes the change in the literary aesthetics of her/his time through her/his own literary selffashioning.

In this respect, Chaucer the pilgrim's function as a tale-teller in the Canterbury Tales, that is, his role in the narrative structure of the Canterbury Tales, is very important. Firstly, he is to tell a verse romance, The Tale of Sir Thopas, and then he switches to a philosophical narrative, The Tale of Melibee, in prose. The role of Chaucer the pilgrim is so significant that he is the only pilgrim to tell a new tale after his tale has been interrupted. For instance, the Monk's tale is also interrupted by another pilgrim, the Knight, but the Monk is not given a second chance to tell a new tale (VII 2767-2807; hroughout this article, all the references to The Tale of Sir Thopas and The Tale of Melibee are from The Riverside Chaucer (2008), Ed. Larry D. Benson, 3rd ed., Oxford). Accordingly, the main point in relation to the role of Chaucer the pilgrim in the Canterbury Tales is to question why Chaucer the poet gives such a chance to Chaucer the pilgrim. Why does Chaucer the poet not give this chance to another pilgrim but only to Chaucer the pilgrim? Why does he let the Host interrupt The Tale of Sir Thopas but not interrupt The Tale of Melibee, which has not been appreciated as much as The Tale of Sir Thopas by Chaucer's critics, although some really praise its philosophical aspect? In the light of these questions, this article aims first to analyse Chaucer the pilgrim's switch from romance to philosophical narration, and then to discuss why Chaucer the poet presents the approval of the fictional pilgrim audience not towards an unrealistic romance in verse, but towards a realistic, philosophical narrative in prose. This transition from unrealistic verse romance to realistic prose philosophical narrative will be evaluated as a reflection of Chaucer's literary self-fashioning. This self-fashioning is a product not only of the change in Chaucer's own literary aesthetics, but also of his concern about fashioning the literary aesthetics of his time, since Chaucer both reflects the changes in the literary aesthetics of his society and has a great influence on shaping this change through his works.

To start with the discussion of The Tale of Sir Thopas, the Host invites Chaucer the pilgrim to tell "a tale of myrthe" (VII 706) and "[s]om deyntee thyng" (VII 711) following the Prioress's tale. Chaucer the pilgrim states that he will tell "of myrthe and of solas" (VII 714), namely, happiness and joy, and begins narrating a popular romance. He tells the tale of a knight from Flanders, named Sir Thopas, until he is interrupted by the Host. In accord with the expressed dislike of the Host, The Tale of Sir Thopas has not received much approval from the 
critics. It has been defined as a "burlesque" (Berry 1994, 155 ; Moore 1954: 532; Linn 1936: 300; Burrow 2003, 146; Hamel 1980, 252), "a parody" (Bloomfield 1986, 185; Brantley 2013, 421), "a farce" (Berry 1994, 132) and "a fantasia" (Gaylord 1982, 320) as well as "the most horrendous doggerel imaginable from the pen of a court poet" (Daileader 1994, 27).

The Tale of Sir Thopas is rooted in popular medieval romances, which presented adventurous episodes from a knight's life. Romance generally has a repetitive structure and set scenes, recurrent images and symbols (Ashton 2010, 20). Romance illustrates episodic adventures from the life of a knight through some stereotypical elements such as supernatural events and characters, magic, stereotypical characters, quest, courtly love, chivalric hero, a love triangle and fighting (Barron 1987, 1-9, Ashton 2010, 2). It depicts the adventures of a hero and reflects his maturation process through the course of an allegorical or symbolic quest motif. In the Middle Ages, romance was highly appreciated by the nobility and the poets including Chaucer. However, as Boitani notes, "Chaucer's romances are the watershed in the development of the genre" $(1982,38)$. Contrary to the popular romances of the thirteenth and early fourteenth centuries, which gave more attention to the style with tail rhyme lines rather than the content, Chaucer "introduced a more sophisticated form" to the changing public taste of the fourteenth century (Boitani, 1982: 39), which can be observed, for instance, in his Troilus and Criseyde, The Wife of Bath's Tale and The Knight's Tale.

Yet, Chaucer's The Tale of Sir Thopas is not a conventional romance, but a parodic romance satirising the element of the supernatural and exaggeration in romances. It "alludes to tail-rhyme romance" (Brantley 2013, 421), and is designed as a parody of popular romances. It parodies the story of a so-called flower of chivalry, Sir Thopas, following the typical features of romance in terms of both content and style. Through tail-rhymed lines, Chaucer the pilgrim defines Sir Thopas's physical attributes from his face to his hair and his costume. He also praises the knight's abilities in hunting and archery, which are proper for a romance hero. Despite these stereotypical features, Sir Thopas is not a typical romance hero, but a parodic figure. Referring to the ladies' interest in Sir Thopas, Chaucer the pilgrim praises his chastity. His exaggerated physical features are accompanied by his self-created love for an imaginary elf-queen who is not known to him, which enhances the parody in relation to the courtly love tradition. One day, while hunting, Sir Thopas contemplates an elf-queen, of whom he has dreamt the night before. Thinking that only that elf-queen can be his match, Sir Thopas decides to go to the land of fairies to be able to find her. Arriving there, he meets first the giant Sir Olifaunt and offers a single combat the following day when he has his armoury. This scene shows that although Sir Thopas seems to be ready to fight for his lady love, he does not bear his arms properly. Furthermore, Sir Thopas stands out as a parodic figure with his beloved, a small elf-queen, and his opponent, a giant, Sir Olifaunt. Accepting Sir Thopas's challenge, Sir Olifaunt ingloriously starts throwing stones at him, which is contrary to the requirements of his title to fight in a noble way. This contributes not only to humour but also to parody in the tale, and totally destroys the element of realism.

Evidently, The Tale of Sir Thopas has all the features to be defined as a parodic romance. As Severs suggests, in The Tale of Sir Thopas, Chaucer does not, in fact, criticise romance as a genre, but its episodic and repetitive pattern, its stereotypical diction, the element of exaggeration as well as the stereotypical depiction of a knight and his adventures $(1979,280)$. Therefore, The Tale of Sir Thopas moves one step further from the already unrealistic romances through its exaggerated unrealism. The lady of romances becomes an elf-queen, the opponent of the lover, who is a parodic knight, becomes a giant, who is "dubbed" 'Sir' (Burrow 2003, 148). 
All the adventure is created by Sir Thopas himself just for the sake of adventure, and he has no psychological depth to set an example for knights-in-the-making. Rather, Sir Thopas is presented as a mock-romance-hero. As a product of exaggeration, he does not conform to the idealistic features of the typical chivalric hero. Although he is defined as the flower of chivalry by Chaucer the pilgrim (VII 901-902), he does not seem to have a plan to display his military skills. He is to fight for love; yet, he himself devises this quest, which seems make no contribution to his maturation process. Moreover, he is not even aware of for whom he is to fight. Therefore, The Tale of Sir Thopas provides the reader with no sense of realism. It presents Chaucer the pilgrim, with his six line tail-rhymed stanzas, "as a teller of memorized rhymed tales - a kind of gestour" (Olson, 1986: 108). However, although Tschann suggests that Chaucer the pilgrim's Tale of Sir Thopas displays his "incompetence" as a tale-teller (1985: 7), it should be noted that Sir Thopas is the "puppet" of Chaucer the pilgrim in The Tale of Sir Thopas, and he stands out as the reflection of the idea that "[a] literal puppet is manipulated by a surrogate human being, who is in turn operated by a real person" (Haskell 1975, 259). Sir Thopas is a 'puppet' controlled by Chaucer the pilgrim, who is himself a 'puppet' in the hands of Chaucer the poet. Hence, although Burrow argues that Chaucer was not as good at writing romance as he was good at writing fabliaux or saint life (2003: 143, 146), The Tale of Sir Thopas with its parodic features reflects not Chaucer's disinterest and unease, but his interest and efficiency in incorporating the romance genre into the Canterbury Tales. Chaucer's wit is reflected by the unrealism of the tale, which is an important feature of the tale (Hamel 1980, 256). Thus, what makes The Tale of Sir Thopas such a distinctive mock-romance is its concern with un/realism.

Bloomfield explains realism as "[f] idelity to actuality, to a true representation of the world, both outer and inner" (1986: 179), none of which can be observed in The Tale of Sir Thopas. The tale does not provide any psychological depth for the characters to present their inner world and any realistic depiction of the events. Chaucer the pilgrim goes far beyond the borders of realism in The Tale of Sir Thopas. Actually, 'traditional' romances are already full of unrealistic elements but, as a parodic romance, the tale further increases the unrealistic elements. In this way, The Tale of Sir Thopas displays "the vanity of a style that becomes its own subject" (Gaylord 1982, 326). Accordingly, as Burrow also asserts, the tale can be defined as "a pointed burlesque, not of romance in general, but of the English romances of his [Chaucer's] day" (Burrow 2003, 147) and their concern with style rather than content. Therefore, the tale can also be regarded as a reflection of Chaucer's literary self-fashioning by drawing attention to his criticism of popular verse romances.

The Tale of Sir Thopas has already been regarded as the criticism of "the ascertainable circumstances of literary production and dissemination at the close of the fourteenth century" (Moore, 1954: 532). In accord with the arguments about literary self-fashioning, The Tale of Sir Thopas also displays Chaucer's reflection of the change in the literary aesthetics of his time and his role in influencing this change through criticising popular verse romances. At the centre of this criticism are the minstrels, who commit "literary crimes" with their rhymes (Moore, 1954: 536). Similarly, Chaucer the pilgrim's style in the telling of The Tale of Thopas presents him as a version of those minstrels. Chaucer the pilgrim is presented in The Tale of Sir Thopas as " $a$ cardboard versifier willing to deliver the tale requested," and the Host regards him as "a pedestrian versifier" (Olson 1986, 105, 106). He performs his role as a tale-teller with his rhyming lines but cannot present a realistic tale. This is the reflection of the idea that Sir Thopas as a parodic romance hero is "a literal puppet of the puppet," that is of Chaucer the pilgrim (Haskell 1975, 253). Chaucer the poet controls the strings of his 'puppet,' Chaucer the pilgrim, who controls the strings of his own 'puppet,' Sir Thopas. Therefore, letting his pilgrim audience 
reject an unrealistic verse romance through the intervention of the Host, Chaucer the poet renounces the authorial authority of Chaucer the pilgrim. In this way, Chaucer the poet implies that the decision about the artistic quality of the tale belongs to the audience/readers, which can be interpreted as a reflection of Chaucer's fashioning of the literary aesthetics of his time. Presenting his pilgrim audience criticise the style of Chaucer the pilgrim's tale about the socalled adventures of Sir Thopas, Chaucer both presents and shapes the change in the literary aesthetics of his time. As a man who is, by his profession as an innkeeper, familiar with the wandering minstrels, it is proper for Harry Bailly to intervene in Chaucer the pilgrim's The Tale of Sir Thopas (Moore 1954, 537):

'Namoore of this, for goddes dignitee,'

Quod oure Hooste, 'for thou makest me

So wery of thy verray lewednesse

That, also wisly God my soule blesse,

Myne eres aken of thy drasty speche.

Now swich a rym the devel I biteche!

This may wel be rym doggerel,' quod he. (VII 919-925)

Letting the Host interrupt The Tale of Sir Thopas, Chaucer the poet aims at not only arousing discontent but also giving voice to public discontent towards popular romances, which were mostly composed of style without much context. Hence, while going on depicting Sir Thopas's dressing up for the combat and his armoury after his return to his town to prepare for the single combat with Sir Olifaunt, Chaucer the pilgrim is interrupted by the Host to tell of something 'more valuable' in prose (VII 919-935). He says that "[s]o wery of thy verray lewedness / That [...], / Myne eres aken of thy drasty speche" (VII 921-923). The Host explicitly states his dislike for Chaucer the pilgrim's tale of Sir Thopas, which seems to be the reflection of a general dislike for the tale among the Canterbury pilgrims. Nobody insists that they want to go on listening to the tale of Sir Thopas. Presenting his fictional pilgrim audience's silence against the Host's interruption, Chaucer the poet gives voice to a silent resistance of the pilgrim audience to any such kind of unrealistic narratives.

After interrupting Chaucer the pilgrim's tale of Sir Thopas, the Host requires him to tell another tale not only because of its content but also because of its style. Referring to Chaucer the pilgrim's "drasty rymyng", the Host also criticises his style, which makes the Host's "eres aken":

"By God,' quod he, 'for pleynly, at a word,

Thy drasty rymyng is nat worth a toord!

Thou doost noght elles but despendest tyme.

Sire, at o word, thou shalt no lenger ryme.

Lat se wher thou kanst tellen aught in geeste,

Or telle in prose somwhat, at the leeste,

In which ther be som murthe or som doctrine" (VII 929-935).

In return for this request, Chaucer the pilgrim says that he will tell "a litel thyng in prose" (VII 937), "a moral tale vertuous" (VII 940), "litel tretys" (VII 957). He starts a more realistic philosophical narration in prose, and tells the tale of Melibee, his wife Prudence and daughter Sophie. One day, Melibee leaves his wife and daughter at home and goes to the fields. Taking advantage of his absence, three of his foes break into his house, beat his wife and wound his daughter almost to death. In grievance for what has happened, Melibee does not know what to 
do and follows the advice of his wife and invites his friends and family members, among whom are surgeons, physicians, advocates, old and young people, to ask for advice. Assembling them, Melibee says that he is full of vengeance and ready for a war on his foes and asks their advice. Most of them are for war and Melibee agrees with them. Although Prudence wants him not to hasten, Melibee says that he cannot follow her advice because of patriarchal and misogynist reasons, all of which are refuted by Prudence. She convinces him to trust her, and starts giving advice to Melibee on how to choose his advisors, how to examine their advice and how to change plans without dishonour.

Although The Tale of Melibee is really very long (especially when listened to) and full of monotonous advices, none of the Canterbury pilgrims intervene in the narration. On the contrary, the Host again becomes the mouthpiece of the pilgrim audience (VII 1889-1896) and his approval of The Tale of Melibee can be regarded as the general approval of a more realistic narrative in prose. In this respect, The Tale of Melibee appears as "the very antithesis" of The Tale of Sir Thopas displaying the distinction between serious philosophical narratives and popular verse romances (Moore 1954, 538). This can also be interpreted as a reflection of the pilgrim audience's evaluation of unrealistic and realistic narratives. In line with these, although for Chaucer's critics The Tale of Melibee has been "the least popular of the Canterbury Tales" (Foster 2008, 409), it is functional in depicting the change in Chaucerian aesthetics and in Chaucer's literary self-fashioning.

Being more realistic than The Tale of Sir Thopas, The Tale of Melibee is different from The Tale of Sir Thopas not only in terms of content, but also in terms of style. It consists of "a string of proverbs and moral apophthegms" (Bloomfield, 1986, 188, For instance, see lines VII 1030, 1048A, 1054, 1135, 1215, 1264-64A, 1794-95) Therefore, it has been defined as a "If]ormal allegory" (Miller 1979, 337) and a "popular exemplary tale" (Collette 1995, 419). The didactic nature of the narration is to set an example to the readers and listeners, and requires a more realistic narrative. Teaching the ideals of reasoning and foresight, Prudence is the teacher not only of Melibee but also of medieval (and contemporary) readers. Explaining to him his failure in choosing his advisors, Prudence advises Melibee not to choose foreigners, young folk, flatterers and reconciled enemies but instead old, experienced and wise friends and family members as advisors. Melibee accepts his fault and decides to change his advisors and Prudence helps him examine what his current advisors said to find out the best ones. She advises him to be patient, to avenge himself by law and not to undermine the power of his enemies. She teaches him how to gather and use riches and to make peace with his adversaries. In the end, he yields to Prudence's advice and forgives his adversaries. Although The Tale of Melibee presents the depiction of an aristocratic world, the decision making process is an important process for everybody and being prudent is presented in the tale as the ideal state of being. In this respect, although it has been claimed that The Tale of Melibee is a dull tale even for " $a$ docile fourteenth-century audience" (Foster 2000, 401), it is necessary to note that The Tale of Melibee provides the reader with a realistic, didactic narrative presenting a familiar setting and a familiar scene, that is, the discussion between a husband and a wife to reach a decision in order to settle a problem, and it becomes "a parable" (Hill 2012, 370) unlike the unrealistic Tale of Sir Thopas.

As for the style, although The Tale of Melibee has been defined as "not crafty" (Yeager 2014, 309), and although it has been claimed "that the pedestrian technique of the Melibeus ran counter to Chaucer's artistic tastes" (Miller 1979 338), stylistically and linguistically it has special features. Although it is not an original work but a rewriting of Renaud de Louens' Livre 
de Mellibee et Prudence, which is itself a translation of Albertanus Brescia's Liber consolationis et consilii (Moore 1954, 539, Bornstein 1978, 237), the originality of The Tale of Melibee lies in Chaucer's style. As Diane Bornstein argues, while imitating the features of his source text in terms of style, Chaucer also "added subordinate clauses and phrases to sentences to create trailing, asymmetric structures; introductory phrases that are often literal translations from the French; and doublets" (1978, 237). In this respect, since Chaucer the pilgrim presents The Tale of Melibee "as the solution to an aesthetic problem" referring to the "sensory displeasure" of the Host towards The Tale of Sir Thopas (VII 923-932), The Tale of Melibee stands out as the opponent of The Tale of Sir Thopas, which is "[a]ll form and no content" (Taylor 2005, 298). Therefore, The Tale of Melibee can be defined as the harmony between content and form. This harmony is enhanced by the use of doublets, which actually constitute "the stylistic signature of the tale" (Taylor 2005, 298). The use of doublets, such as "warisshe and escape" (VII 983) or "myght and power" (VII 1753), is very important, both stylistically and linguistically in that, in addition to being an "aesthetic form," the use of doublets is also linguistically important. Doublets introduce and explain new words, which influence the development of the English language as well (Taylor 2005 299, 313). Therefore, the use of doublets contributes to enhance not only the influence of content through explanations, but also the stylistic beauty, which also enhances Chaucer's fame as the father of English 'language' and literature.

Accordingly, if it is remembered that the Canterbury Tales includes almost all of the literary genres of medieval English literature, from saint's lives to exempla, from romances to fabliaux, as a result of which the Canterbury Tales has been defined as "a remarkable anthology of medieval literature" by A. C. Baugh $(1967,262)$, the genres that are contested by Chaucer the pilgrim appear to be unrealistic popular romances (exemplified by The Tale of Sir Thopas) and realistic philosophical narratives (exemplified by The Tale of Melibee). Presented as an alternative to The Tale of Sir Thopas, The Tale of Melibee helps Chaucer the pilgrim/poet compare and contrast "minstrelism and prudential counsel" (Leitch 2012, 409). This comparison is also related to the change from oral to literary culture, because, as Dieter Mehl indicates, The Tale of Sir Thopas and The Tale of Melibee "represent the two extremes of oral and literary narrative, of popular entertainment and bookish instruction" (1986, 221). Prudence's constant references to secular and religious authorities ranging from Ovid, Seneca, Petrus Alphonsus, Cicero, Cato, Aesop and Cassiodorus to the Bible, the doctrines of St. Paul and St. Jerome both reveal her knowledge of them and draw attention to knowledge coming from written authorities. In this respect, what David Raybin and Susanna Fein argue about the poet of the Book of Duchess is also valid for the poet of the Canterbury Tales: Chaucer the poet constantly depicts his "sustained self-representation as a writer concerned with the artistic possibilities of language" $(2005,226)$. Likewise, the link between The Tale of Sir Thopas and The Tale of Melibee reveals Chaucer the pilgrim-narrator not "as an individualized character in his own right, but primarily as a writer and story-teller" (Miller 1979, 221). In line with these, it is necessary to discuss the role of Chaucer the pilgrim in relation to his choice of these two tales to "have a soper" at all the other pilgrims' cost (I (A) 799). After all, as Benson states, "[t]he real contest in the Canterbury Tales is between poems not pilgrims," and the contest between The Tale of Sir Thopas and The Tale of Melibee is their "artistic opposition" (1983, 61, 65). Hence, Chaucer the pilgrim's function as a tale teller and as the narrator stands out as an important element in this literary contest revealing Chaucer the poet's literary self-fashioning.

Chaucer the pilgrim is an example of the "authorial ' $I$ " which is created by the poet to contribute to realism (Bloomfield 1986, 181). This fictional 'I,' in fact, does not come to the 
foreground in the Canterbury Tales, because Chaucer the pilgrim is just to re-tell the tales that have been told by others. Hence, Chaucer the pilgrim assumes a secondary position in the narration. Yet, it should not be disregarded that both the tales Chaucer the pilgrim claims to retell and Chaucer the pilgrim's own tales are, in fact, the creations of Chaucer the poet, who is the master narrator. At this point, although E. Talbot Donaldson argues that Chaucer the pilgrim and Chaucer the poet should not be considered to be the same person, since Chaucer the pilgrim is just a "fictional reporter" and not the real poet, there should be a reason (or motive) as to why Chaucer the poet creates Chaucer the pilgrim $(1970,1)$. Although the poet and the pilgrim Chaucer are distinct from each other, Chaucer the pilgrim is still functional in reflecting the poet's set of mind. While "Chaucer the poet [...] operates in a realm which is above and subsumes those in which Chaucer the man and Chaucer the pilgrim have their being" (Donaldson 1970,11), he also takes advantage of the role of Chaucer the pilgrim not only to reflect the change in the literary aesthetics of his time, but also to influence this very change (See Paul Strohm for a discussion of this interaction, 1989: ix-xiii.). As a result, when the Host invites Chaucer the pilgrim to tell a tale, there appears "a pilgrim Chaucer so limited as a raconteur that he can manage nothing better than the egregious [Tale of Sir Thopas]" (Wood, 1972: 389). However, Chaucer the pilgrim's move from a popular verse romance towards a philosophical prose narrative is both a reflection and a product of the changes in Chaucer's literary aesthetics. It is also the reflection of the change in the literary aesthetics of the fourteenth century, which moved away from popular unrealistic verse romances towards realistic, prose narratives. This move towards philosophical prose narratives is the reflection of the turn to classical literature as also reflected by the works of Chaucer's contemporary poets such as Gower's Mirroir de L'Omme and Confessio Amantis, and the works of Usk and Hoccleve (Olson 1986, 112). In this respect, The Tale of Melibee can be defined as "an aesthetic practice," which aimed at influencing its listeners'/readers' literary aesthetics (Taylor 2005, 317). Chaucer appears not only as a mirror to reflect this change as a poet, but also as the trigger of this aesthetic change, which draws attention to his role in fashioning the literary aesthetics of his time.

Accordingly, turning back to the arguments of literary self-fashioning, it can be claimed that through his literary exercises in The Tale of Sir Thopas and The Tale of Melibee, Chaucer exhibiting his own literary self-fashioning argues for realistic and didactic works in prose rather than popular verse romances. Apparently, Chaucer "has no respect for art that is only wishfulfillment unconnected to the reality of the world outside" (Olson 1986, 123). This shows that, among many genres, Chaucer prefers more realistic, didactic prose works, rather than unrealistic, popular verse romances. This choice, on the one hand, reflects the change in court aesthetics (Olson 1986, 109-110), which "signals the collapse of minstrel pretensions on the literary level" as exemplified by The Tale of Sir Thopas (Moore 1954, 545). On the other hand, The Tale of Melibee becomes both a product and a trigger for this aesthetic change. Hence, The Tale of Sir Thopas and The Tale of Melibee become "essentially critical exercise[s]" (Moore, 1954: 545). They constitute a practice favouring prudence not only on socio-political level (Collette 1995, 421), but also on a literary level. In order to exemplify this, it is necessary to note the impact of Chaucer's approval of didactic prose narratives on the prose works of the fifteenth century.

Beginning from the late fourteenth century onwards and in the fifteenth century, prose became more and more dominant, as reflected in the emergence of "the style curial or the style clergial" (Bornstein 1978, 237). It actually developed in Latin but, then, it was also used in vernacular writings. The main characteristics of this style were "the use of formulaic 
expressions, terms of reference (dessusdit, le dit, cette dit), introductory phrases, Latinate words, elaborate explanations, legal phrases, synonyms (particularly doublets), reliance on the passive voice, and a grave, ceremonious tone" (Bornstein 1978, 237). Chaucer was the one to adopt this style, but he adopted it not through mere "imitation", but through "cultivation", and he became one of the first English men of letters, who introduced this prose style, the style clergial, and set an example tothe other writers in the fifteenth century when this specific prose style became very popular (Bornstein 1978, 240). His influence on the prose works of fifteenth century writers casts light upon his role in fashioning the literary aesthetics of the fifteenth century. Chaucer reflects his concern about the impact of his literary exercises on his readers in the Retraction (Mehl 1986, 222). In the Retraction, Chaucer expresses his worry about the influence of his 'book', the Canterbury Tales, on his audience/readers, and sounds apologetic in his address to his audience "if ther be any thyng that displese hem" (X (I) 1082). Still, he leaves the decision to the reader, which emphasises the " 'auctoritee' of audience over author" (Daileader 1994, 28). Evidently, Chaucer is concerned about the influence of his literary selffashioning, which would have an impact on the fashioning of the literature of his time and in the following periods.

To conclude, furthering Greenblatt's arguments in relation to the self-fashioning concept and the role of writers in fashioning 'other selves,' Chaucer's The Tale of Sir Thopas and The Tale of Melibee in the Canterbury Tales can be regarded as the means to discuss literary selffashioning and in fashioning the change in literary aesthetics. Chaucer the pilgrim's switch from an unrealistic popular verse romance (The Tale of Sir Thopas) to a more realistic prose narrative (The Tale of Melibee) can be regarded as a reflection of Chaucer the poet's literary selffashioning. Chaucer the poet's presentation of the fictional pilgrim audience's approval of The Tale of Melibee, which is defined as "litel thyng in prose" by Chaucer the pilgrim (VII 937) and the disapproval of The Tale of Sir Thopas, which is defined as "the beste rym I kan" by Chaucer the pilgrim (VII 928), reflects both the change in Chaucerian aesthetics and Chaucer's influence on the change in the literary aesthetics of his time. Therefore, The Tale of Sir Thopas and The Tale of Melibee should be regarded a reflection and a product not only of Chaucer's literary self-fashioning, but also his fashioning of the literary aesthetics of his time (and beyond).

\section{REFERENCES}

Ashton G. (2010). Medieval English Romance in Context. London - New York 2010.

Barron W. R. J. (1987). English Medieval Romance. London - New York 1987.

Baugh A. C. (1967). A Literary History of England. Vol. I. London 1967.

Benson C. D. (1983). "Their Telling Difference: Chaucer the Pilgrim and His Two Contrasting Tales". The Chaucer Review 18/1 (1983) 61-76.

Berry C. A. (1994). "Borrowed Armor/Free Grace: The Quest for Authority in The Faerie Queene and Chaucer's Tale of Sir Thopas". Studies in Philology 91/2 (1994) 136-166.

Bloomfield, Morton W. (1986). "Chaucerian Realism". Eds: Piero Boitani and Jill Mann The Cambridge Chaucer Companion (1986) 179-193. Cambridge.

Boitani P. (1982). English Medieval Narrative in the Thirteenth and Fourteenth Centuries. Trans. Joan Krakover Hall. Cambridge 1982.

Bornstein D. (1978). "Chaucer's Tale of Melibee as an Example of the Style Clergial". The Chaucer Review 12/4 (1978) 236-254. 
Brantley J. (2013). "Reading the Forms of Sir Thopas". The Chaucer Review 47/4 (2013) 416-438.

Burrow J. A. (2003). "The Canterbury Tales I: Romance". Eds. Piero Boitani and Jill Mann The Cambridge Companion to Chaucer (2003) 143-159. Cambridge.

Chaucer G. (2008). The Riverside Chaucer. Ed. Larry D. Benson. 3rd edition. Oxford 2008.

Collette C. P. (1995). "Heeding the Counsel of Prudence: A Context for the Melibee". The Chaucer Review 29/4 (1995) 416-433.

Daileader, Celia R. (1994). "The Thopas-Melibee Sequence and the Defeat of Antifeminism". The Chaucer Review 29/1 (1994) 26-39.

Donaldson E. T. (1970). Speaking of Chaucer. New York 1970.

Foster E. E. (2000). "Has Anyone Here Read Melibee?" The Chaucer Review 34/4 (2000) 398-409.

Foster M. (2008). "Echoes of Communal Response in the Tale of Melibee". The Chaucer Review 42/4 (2008) 409-430.

Gaylord A.T. (1982). “The Moment of 'Sir Thopas:' Towards a New Look at Chaucer's Language”. The Chaucer Review 16/4 (1982) 311-329.

Greenblatt S. (2005). Renaissance Self-Fashioning: From More to Shakespeare. Chicago 2005.

Hamel M. (1980). “And Now for Something Completely Different: The Relationship between the Prioress's Tale and the Rime of Sir Thopas". The Chaucer Review 14/3 (1980) 251-259.

Haskell A. S. (1975). “Sir Thopas: The Puppet's Puppet”. The Chaucer Review 9/3 (1975) 253-261.

Hill T. D. (2012). "Chaucer's Parabolic Narrative: The Prologue to the Tale of Melibee, Lines 953-58". The Chaucer Review 46/3 (2012) 365-370.

Leitch M. G. (2012) "Locating Authorial Ethics: The Idea of the Male or Book-Bag in the Canterbury Tales and Other Middle English Poems". The Chaucer Review 46/4 (2012) 403-418.

Linn I. (1936). “The Arming of Sir Thopas". Modern Language Notes 51/5 (1936) 300-311.

Mehl D. (1986). "Chaucer's Narrator: Troilus and Criseyde and the Canterbury Tales". Eds. Piero Boitani and Jill Mann The Cambridge Chaucer Companion (1986) 213-226.

Miller R. P. (1979). "Allegory in the Canterbury Tales". Ed. Beryl Rowland Companion to Chaucer Studies (1979) 326-351. New York - Oxford 1979.

Moore A. K. (1954). “Sir Thopas' as Criticism of Fourteenth-Century Minstrelsy”. The Journal of English and Germanic Philology 53/4 (1954) 532- 545.

Olson P. (1986). The Canterbury Tales and the Good Society. Princeton 1986.

Raybin D. \& Fein S. G. (2005). "Chaucer and Aesthetics". The Chaucer Review 39/3 (2005) 225-233.

Severs B. J. (1979). "The Tales of Romance”. Ed. Beryl Rowland Companion to Chaucer Studies (1979) 271-295. New York - Oxford 1979.

Strohm P. (1989). Social Chaucer. Cambridge - Massachusetts 1989.

Taylor K. (2005). "Social Aesthetics and the Emergence of Civic Discourse from the Shipman's Tale to Melibee". The Chaucer Review 39/3 (2005) 298-322.

Tschann J. (1985). "The Layout of 'Sir Thopas' in the Ellesmere, Hengwrt, Cambridge Dd.4.24, and Cambridge Gg.4.27 Manuscripts". The Chaucer Review 20/1 (1985) 1-13.

Wood C. (1972). "Chaucer and 'Sir Thopas': Irony and Concupiscence”. Texas Studies in Literature and Language 14/3 (1972) 389-403.

Yeager S. (2014). “Chaucer's Prudent Poetics: Allegory, the Tale of Melibee, and the Frame Narrative to the Canterbury Tales". The Chaucer Review 48/3 (2014) 307-321. 